\title{
Exports as a Determinant of Inflation in Kenya: Disaggregated Econommetric Analysis
}

\author{
Evans Ovamba Kiganda \\ Tutorial Fellow Technical University of Mombasa \\ Dr. Scholastica Adhiambo \\ Lecturer department of economics, Maseno University, Kenya \\ Dr. Nelson Obange \\ Lecturer department of economics, Maseno University, Kenya
}

doi: 10.19044/esj.2017.v13n10p417 URL:http://dx.doi.org/10.19044/esj.2017.v13n10p417

\begin{abstract}
The purpose of this study was to examine exports as a determinant of inflation in Kenya: A disaggregated econometric analysis with specific objectives of establishing the relationship between domestic exports and inflation in Kenya and determining the relationship between re - exports and inflation in Kenya. This was occasioned by inconclusive and incomprehensive analysis on the relationship between exports and inflation given mixed results and failure by scholars to disaggregate total exports into domestic exports and re-exports. Correlation research design was employed using monthly time series obtained from Central Bank of Kenya (CBK) data spanning 132 months from January 2005 to December 2015.Vector Autoregressive (VAR) techniques of cointegration, Granger causality and impulse response analysis were employed. Results indicated a significant positive and negative long run relationship between domestic exports and reexports with inflation in Kenya respectively that were supported by the impulse response analysis. A unidirectional causality running from domestic exports to inflation and re-exports to inflation was also established. The study concluded that domestic exports and re-exports determine inflation in Kenya with domestic exports having greater influence and therefore recommended that the government of Kenya needs to advocate for a trade policy that aims at reducing exports of domestically produced products and increase re-exports. This will ensure that only surplus is exported to reduce shortage of domestically produced commodities hence a reduction in price for the products.
\end{abstract}

Keywords: Exports, inflation, disaggregate analysis, Kenya 


\subsection{Introduction}

Economic globalization has increased connectivity and interdependence of markets and businesses by removing restrictions and barriers on exchange of knowledge and products across the borders promoting exports and imports (Ramzan, Fatima, \& Yousaf, 2013). Exports is among the mainstay economic activities of the world's population that contributes to economic growth, both directly, because exports are part of production, and indirectly by facilitating imports of goods and services, and of new ideas, knowledge and technology (Gylfason, 1997). Increased exports also give a guarantee of financial economic stability of a country, this is one of the ways to suck money from the economies of diversified nations and inject into the home economy such that through the help of this foreign exchange the home country progresses (Khan, 2013). However, increase in exports as outlined by Shah et al. (2014) and Bashir et al. (2011) not only is it beneficial to the economy but also deterimental as it promotes inflationary pressures in the economy by increasing aggregate demand.

Total exports in Kenya have been increasing over years where it rose by 8.2 per cent to KSh 581 billion in 2015 (Government of Kenya, 2016) but no study has attempted to analyze how exports relate with inflation in Kenya. On the other hand, studies on the exports - inflation relationship conducted world over such as Venkadasalam (2015); Ahmed et al. (2013); Joiya and Shahzad (2013); Jaradat et al. (2011) among others depicted mixed results and failed to disaggregate total exports into domestic and re-exports. This meant lack of information on the effect of domestic exports and re-exports on inflation as components of total exports. Thus the available studies are inconclusive in providing a comprehensive analysis for the relationship between exports and inflation. This study therefore determined the relationship between exports and inflation in Kenya by employing vector autoregressive (VAR) analysis techniques using total exports components of domestic exports and re-exports to bridge the gap of inconclusiveness in the analysis of the relationship between exports and inflation.

\subsection{Statement of the Problem}

Studies on the relationship between exports such as Venkadasalam (2015); Ahmed et al. (2013); Joiya and Shahzad (2013); Jaradat et al. (2011) among others lack consensus given mixed results indicating positive and negative relationship and failed to disaggregate total exports into its components such as domestic exports and re-exports. This meant lack of knowledge on effect domestic exports and re-exports on inflation making the findings of available studies on the relationship between exports and inflation inconclusive and incomprehensive. 


\subsection{Objectives}

The purpose of this study was to examine exports as a determinant of inflation in Kenya: A disaggregated econometric analysis.

\subsubsection{Specific Objectives}

i. Establish the relationship between domestic exports and inflation in Kenya.

ii. Determine the relationship between re - exports and inflation in Kenya.

\subsection{Research Hypothesis}

i. Relationship between domestic exports and inflation in Kenya.

$H_{0}$ : There is no significant relationship between domestic exports and inflation in Kenya.

ii. Relationship between re-exports and inflation in Kenya.

$H_{0}$ : There is no significant relationship between re-exports and inflation in Kenya.

The rejection of null hypothesis implied that the alternative hypothesis of existence of significant relationship for each case was accepted.

\subsection{Scope of the study}

This study was based on monthly time series data obtained from the Central Bank of Kenya (CBK) spanning 132 months from January 2005 to December 2015.

\subsection{Significance of the Study}

Kenya's monetary policy objective over years has been the achievement of inflation of below 5 per cent. However, inflation has consistently remained above the target over years. Determinants of inflation remain debatable among scholars given the mixed results reported. Further, their analysis mainly focused on aggregate exports rather than disaggregate exports. This study which involved disaggregating total exports into domestic and re-exports provides uncertain knowledge to policy makers and academia on the relationship between the components of total exports and inflation in Kenya and which of these factors highly influences the relationship. Hence the study forms useful material for regulating inflation in Kenya by advocating targeting of the export component that highly influences inflation. 


\subsection{Literature Review}

\subsection{Exports and Inflation}

Investigating the long run and short run significance of macroeconomic variables such as exports, broad money, gross domestic product and household final consumption expenditure towards the consumer price index in Malaysia Venkadasalam (2015) employed Augmented Dickey-Fuller, Johansen system co-integration, Vector Error Correction (VEC) model tests for the period 1960 to 2012. The results showed that all the variables were integrated of order one, in the long run, broad money, export of goods and services, gross domestic product and household final consumption expenditure were significantly positively related to the consumer price index. This implied that an increase in broad money, exports, gross domestic product and household final consumption expenditure causes inflation to increase. The VECM indicated consumer price index to be error correcting in the short run and there was no causality between the factors and consumer price index and. As much as the study employed robust analysis techniques, the failure to employ impulse response and variance decomposition makes the study inadequate in outlining the relationship between exports, broad money, gross domestic product and household final consumption expenditure with consumer price index. This is attributed to the fact that knowledge on how shocks in the factors influence consumer price index remains uncertain.

Jaradat et al. (2011) examined factors affecting inflation in Jordan using quarterly data from 2000 to third quarter of 2010 by applying the concepts of cointegration, Error Correction Model, analysis of Variance Decomposition and Impulse Response Function. The results indicated that the variables of national exports, imported inflation, credit facilities, GDP, money supply were and inflation were integrated of order one. National exports, imported inflation and credit facilities had a positive long run relationship with inflation. It was also noted GDP had a negative relationship with inflation while money supply had an insignificant effect on inflation in Jordan. The impulse responses and variance decomposition analysis also indicated that shocks on national exports, imported inflation, GDP, credit facilities and money supply influenced inflation from the second period in Jordan. Despite the employment of robust data analysis techniques in this study, lack of causality analysis makes the study inconclusive in providing a comprehensive overview of relationship between inflation and its determinants of national exports, imported inflation, GDP, credit facilities and money supply and inflation. This is because the study failed to answer the direction of causality among the variables.

Joiya and Shahzad (2013) analyzed the determinants of high food prices in Pakistan using Autoregressive Distributed Lag approach and error 
correction model for long-run and short-run, respectively based on time series data for the period 1972-73 to 2009-10. The findings of the study showed that food exports contributed towards high food prices while food imports caused the reduction in the food prices. Similarly, Rehman and Khan (2015) in investigating the factors affecting food price inflation in Pakistan during 1990-2013 by applying econometric tests of Augmented Dickey Fuller, Vector Error Correction model and Johansen co-integration test showed that all the variables were integrated of order one and that food exports had positive and significant long run impact on food price inflation in Pakistan. They concluded that because food inflation occurs due to high demand of food items only those products with excess supply should be exported. In spite of the fact that the studies employed different cointegration techniques for varying time periods they consented on the positive effect of food exports on inflation. However, their studies fell short of conducting causality, impulse response and variance decomposition analysis. This makes the findings inadequate in providing a conclusive relationship analysis between food exports and inflation given that there are uncertainties on the direction of causality and how a shock in food price influences inflation.

Ahmed et al. (2013) in exploring determinants of inflation in Pakistan for the period 1971 to 2012 applied Johansen cointegration and Error Correction Model (ECM). The results showed that exports of goods and services had a significant negative effect on inflation because higher exports increased domestic production which leads the firm to achieve economies of scale and cost of production decline. In the same way, Arif and Ali (2012) analyzed the major determinants of inflation in Bangladesh using data for the period from 1978 to 2010. The findings based on correlation coefficients indicated a weak negative association between imports, exports, government revenue, money supply and inflation. On the other hand, long run analysis indicated that exports had a negative effect on inflation in Bangladesh. Despite the fact that the studies consented on negative effect of exports on inflation, lack of information on the direction of causality and how shocks in exports influence inflation given that causality, variance decomposition and impulse response analysis tests were not conducted makes the studies inconclusive on the relationship between exports and inflation.

Olatunji et al. (2010) examined the factors affecting inflation in Nigeria using time series data were employed for the study. Use of unit root, cointegration and error correction analysis indicated that the study variables were normally distributed and integrated of order one. Total export, interest rate and crude oil exports were found to have a negative impact on inflation while total imports and food price index exerted a positive effect. Total government expenditure had an insignificant effect on inflation with inflation 
in the short run correcting disequilibrium at the rate of $70 \%$ in the next period. The review of the study indicated that important relationship analysis techniques such as causality, variance decomposition and impulse response analysis tests were not utilized making the study findings inconclusive for analyzing relationship between inflation and its determinants of exports, interest rate, crude oil imports and food price index.

The review of studies on the exports and inflation relationship depicted lack of consensus on the relationship between exports and inflation given mixed results. Further, majority of the studies focused on total exports without involving its components of domestic exports and re-exports making their effect on inflation unknown. This made the studies inconclusive in providing a comprehensive analysis for the relationship between exports and inflation. The study therefore determined the relationship between exports and inflation in Kenya by domestic exports and re-exports to bridge the gap of inconclusiveness and incomprehensiveness in the relationship between exports and inflation.

\subsection{Methodology}

\subsection{Research Design and Data analysis}

This study was conducted using correlation research design used to analyze relationship between variables. Robust Vector Autoregressive (VAR) techniques of cointegration test, Granger causality test and impulse response were employed.

\subsection{Model Specification}

The model specification of this study was specified as (3.1) with analysis being conducted based on the VAR model (3.2) of order p. Other variables for the components of money supply, government expenditure, imports and taxation were introduced as intervening variables in the model.

$$
\begin{aligned}
& I_{N F M_{t}}=\alpha_{0}+\alpha_{1} \operatorname{CIMP}_{t}+\alpha_{2} \operatorname{DEVEXP}_{t}+\alpha_{3} \mathrm{DEXP}_{t}+\alpha_{4} E_{t},+\alpha_{5} \operatorname{GIMP}_{t}+\alpha_{6} I_{t} \\
& +\alpha_{7} I T_{t}+\alpha_{8} M 0_{t}+\alpha_{9} M_{t}+\alpha_{10} \text { RECEXP }_{t}+\alpha_{11} \text { REEXP }_{t}+\alpha_{12} V A T_{t}+\mu_{t}
\end{aligned}
$$

Where; INFM ${ }_{t}$ - inflation, Recurrent government expenditure, $D E V E X P_{t}$ - Development expenditure, DEXP $P_{t}$ - Domestic exports, REEXP $P_{t}$ - Re-exports, $M 0_{t}-$ Currency outside banking system, $M 3_{t}-$ $\mathrm{M} 2+$ resident foreign currency deposits, $E D_{t}-$ Excise duty, $I E_{t}-$ Import duty, $I T_{t}-$ Income tax, $V A T_{t}-$ Value added tax, $C I M P_{t}-$ Commercial imports, GIMP $P_{t}$-Government imports, $t$ - time period in months and $\mu$-error term (capturing other factors). 
$z_{t}=A_{1} z_{t-1}+A_{2} z_{t-2}+\ldots+A_{p} z_{t-p}+\mu_{t}$

Where:

$z_{t}=n \times 1$ Vector of variables that are integrated of order one

$\mu_{t}=n \times 1$ Vector of innovations

\subsection{Measurement of Variables}

The variables in this study were measured as below;

Inflation - the Consumer Price Index (CPI) is used in Kenya as the main estimator of inflation whereby the percentage change of the CPI over a one-month period is what is usually referred to as the rate of inflation (Government of Kenya, 2010).

Development Government Expenditure - It is the government expenditure on capital overheads and measured by the total government expenditure less recurrent expenditure (Njuru, 2012; Government of Kenya, 2016).

Recurrent Government Expenditure - It is the current expenditure for purchase of goods and services at all levels of government (Njuru, 2012; Government of Kenya, 2016). It was measured by summing up expenditures incurred by the government on domestic interest, foreign interest, wages and pensions.

Exports of goods and services - represent the value of all goods and other market services provided to the rest of the world which include the value of merchandise, freight, insurance, transport, travel, royalties, license fees, and other services, such as communication, construction, financial, information, business, personal, and government services (World Bank, 2014). They comprise of domestic exports for the export of goods produced within the country and re-exports which goods are bought by the country from other countries but also exported to other countries.

Excise Duty - It is a domestic tax on the production or sale of a commodity in a given country measured by summing up all taxes falling under this category (Njuru, 2012; Government of Kenya, 2016).

Import Duty - It is the tax levied on imports by the custom authorities of a country to raise state revenue or to protect domestic industries from efficient or predatory foreign competitors and measured by aggregating the taxes that fall under this category (Njuru, 2012; Central Bank of Kenya, 2015).

Income tax - This is the tax imposed on income of individuals and companies and measured by aggregating the taxes that fall under this category (Njuru, 2012; Government of Kenya, 2016). 
Value Added Tax (VAT) - This is an indirect tax on the domestic consumption of goods and services levied at each stage in the chain of production and distribution from raw materials to the final sale, based on the value added at each stage. It is derived through summing up of all taxes on value added paid by different agents in the economy (Njuru, 2012; Government of Kenya, 2016).

Imports of goods and services - The value of all goods and other market services received from the rest of the world which include the value of merchandise, freight, insurance, transport, travel, royalties, license fees, and other services, such as communication, construction, financial, information, business, personal, and government services (World Bank, 2014).

2015)

M0 - Currency outside the banking system (Central Bank of Kenya,

M3 - M2+ resident foreign currency deposits. Also referred to as extended broad money (Central Bank of Kenya, 2015)

\subsection{Results and Discussion}

\subsection{Descriptive Statistics}

Table 1 results indicated that the mean values for the variable of inflation rate (INFM) as $8.47 \%$, the maximum and minimum values as 19.70 $\%$ and $1.85 \%$ respectively. The mean values for the variables of domestic exports (DEXP) and re-exports (REEXP) were Sh.30.95 billion and Sh.3.20 billion respectively. The maximum and minimum values for the variables were sh.50.40 billion and sh.14.60 billion respectively for domestic exports (DEXP) and sh.10.30 billion and sh.742.0 million respectively for re-exports (REEXP). The Jarque-Bera test confirmed that the variables of inflation, domestic exports and re-exports were normally distributed at 5\% level of significance since there JB-statistics of were less than $\chi^{2}(2 d f)=5.99147$.

Table 1: Descriptive Statistics

\begin{tabular}{lcccccccccr}
\hline & Mean & $\begin{array}{l}\text { Media } \\
\mathrm{n}\end{array}$ & Max & Min & $\begin{array}{l}\text { Std } \\
\text { Dev }\end{array}$ & $\begin{array}{l}\text { Skewn } \\
\text { ess }\end{array}$ & $\begin{array}{l}\text { Kurto } \\
\text { sis }\end{array}$ & $\begin{array}{l}\text { Jarque- } \\
\text { Bera }\end{array}$ & $\begin{array}{l}\text { P- } \\
\text { value }\end{array}$ & $\begin{array}{r}\text { O } \\
\text { bs }\end{array}$ \\
\hline INFM & 8.470 & 6.695 & 19.72 & 1.850 & 4.827 & 0.0932 & 2.642 & 0.89314 & 0.100 & 13 \\
& 758 & 000 & 000 & 000 & 912 & 71 & 799 & $r$ & 9 & 049 \\
CIMP & 85306 & 78544 & 15967 & 27951 & 35559 & 0.1855 & 3.726 & 3.66380 & 0.077 & 13 \\
& .98 & .50 & 1.0 & .00 & .85 & 78 & 904 & 4 & 939 & 2 \\
DEVE & 96214 & 61617 & 51182 & 174.0 & 96930 & 0.0154 & 2.797 & 0.23040 & 0.069 & 13 \\
XP & .44 & .50 & 2.0 & 000 & .25 & 88 & 685 & 0 & 812 & 2 \\
DEXP & 30950 & 31542 & 50412 & 14570 & 9259. & - & 2.814 & 1.05066 & 0.083 & 13 \\
& .86 & .50 & .00 & .00 & 478 & 0.1978 & 336 & 0 & 616 & 2 \\
& & & & & & 4 & & & & \\
ED & 40449 & 37775 & 11587 & 2687. & 24706 & 0.0383 & 2.071 & 4.77387 & 0.122 & 13 \\
& .42 & .50 & 2.0 & 000 & .05 & 86 & 516 & 0 & 478 & 2 \\
GIMP & 1138. & 733.0 & 7799. & 1.000 & 1266. & 0.0441 & 3.038 & 0.05083 & 0.067 & 13 \\
& 561 & 000 & 000 & 000 & 885 & 06 & 213 & 0 & 901 & 2 \\
\hline
\end{tabular}




\begin{tabular}{lcccccccccr}
\hline ID & 24966 & 21095 & 84512 & 987.0 & 17736 & 0.0667 & 3.871 & 4.28012 & 0.081 & 13 \\
& .54 & .50 & .00 & 000 & .78 & 8 & 99 & 7 & 603 & 2 \\
IT & 13070 & 99642 & 50858 & 6654. & 10508 & 0.0212 & 2.365 & 2.22715 & 0.130 & 13 \\
& 0.3 & .50 & 1.0 & 000 & 4.9 & 08 & 069 & 1 & 000 & 2 \\
M0 & 11195 & 10265 & 19125 & 58042 & 38165 & 0.3157 & 2.826 & 2.35903 & 0.077 & 13 \\
& 4.9 & 6.5 & 1.0 & .00 & .95 & 64 & 54 & 8 & 570 & 2 \\
M3 & 13079 & 12060 & 26501 & 50851 & 63719 & 0.0526 & 2.066 & 4.85864 & 0.064 & 13 \\
& 07. & 71. & 82. & 2.0 & 9.7 & 38 & 026 & 8 & 311 & 2 \\
RECE & 29833 & 24483 & 10756 & 21134 & 21735 & 0.0075 & 3.970 & 5.18419 & 0.976 & 13 \\
XP & 0.9 & 2.0 & 44. & .00 & 3.8 & 09 & 75 & 6 & 010 & 2 \\
REEX & 3216. & 2493. & 10249 & 742.0 & 2147. & 0.0888 & 3.110 & 0.24026 & 0.056 & 13 \\
P & 606 & 500 & .00 & 000 & 773 & 34 & 082 & 2 & 321 & 2 \\
VAT & 82454 & 70182 & 25968 & 3826. & 56160 & 0.3928 & 3.324 & 3.97611 & 0.072 & 13 \\
& .95 & .00 & 5.0 & 000 & .51 & 87 & 79 & 1 & 316 & 2 \\
\hline
\end{tabular}

Source: Author (2017). Note that INFM in \% while other variables $(000,000)$

\subsection{Correlation}

Tables 2 test results indicated that there was a significant weak negative association between re-exports and inflation in Kenya and a significant strong positive association between domestic exports and inflation in Kenya at 5\% level of significance with correlation coefficients $r=-0.32, r=0.74$ with p-values of 0.01 and 0.03 respectively for re-exports and domestic exports. The results indicated that the null hypothesis of no correlation between exports and inflation in Kenya was rejected at 5\% level of significance. This implied that there existed an association between exports and inflation in Kenya whereby an increase in re-exports decreases inflation while an increase in domestic exports increases inflation in Kenya. Comparatively, domestic exports highly influenced inflation as compared to re-exports. The negative association between reexports and inflation was consistent with the findings of Olatunji et al. (2010) who investigated the determinants of inflation in Nigeria while the findings of positive association between domestic exports and inflation in Kenya conformed to the findings of Venkadasalam (2015) who investigated the determinants of inflation in Malaysia. 
Table 2: Correlation Matrix

\begin{tabular}{|c|c|c|c|c|c|c|c|c|c|c|c|c|c|}
\hline & INFM & CIMP & DEVEXP & DEXP & ED & GIMP & ID & IT & M0 & M3 & RECEXP & REEXP & VAT \\
\hline INFM & 1 & & & & & & & & & & & & \\
\hline CIMP & $-0.53^{*}$ & 1 & & & & & & & & & & & \\
\hline \multirow{2}{*}{ DEVEXP } & $-0.03 *$ & $-0.08^{*}$ & 1 & & & & & & & & & & \\
\hline & $(0.01)$ & $(0.34)$ & ----- & & & & & & & & & & \\
\hline \multirow[t]{2}{*}{ DEXP } & $0.74 *$ & $0.35^{*}$ & $-0.18^{*}$ & 1 & & & & & & & & & \\
\hline & $(0.03)$ & $(0.00)$ & $(0.04)$ & ----- & & & & & & & & & \\
\hline \multirow[t]{2}{*}{ ED } & $0.87^{*}$ & -0.02 & 0.01 & 0.04 & 1 & & & & & & & & \\
\hline & $(0.00)$ & (0.86) & (0.95) & (0.67) & ----- & & & & & & & & \\
\hline \multirow[t]{2}{*}{ GIMP } & 0.05 & $0.28^{*}$ & 0.02 & 0.14 & -0.11 & 1 & & & & & & & \\
\hline & $(0.55)$ & $(0.00)$ & (0.83) & $(0.12)$ & $(0.22)$ & ----- & & & & & & & \\
\hline \multirow[t]{2}{*}{ ID } & $0.58^{*}$ & 0.02 & $0.38^{*}$ & -0.08 & -0.07 & $0.32 *$ & 1 & & & & & & \\
\hline & $(0.00)$ & (0.86) & $(0.00)$ & (0.33) & $(0.43)$ & $(0.00)$ & ----- & & & & & & \\
\hline \multirow[t]{2}{*}{ IT } & $-0.57^{*}$ & -0.06 & $0.31 *$ & -0.13 & -0.06 & $0.25 *$ & $0.66^{*}$ & 1 & & & & & \\
\hline & $(0.00)$ & $(0.52)$ & $(0.00)$ & $(0.14)$ & $(0.47)$ & $(0.00)$ & $(0.00)$ & ----- & & & & & \\
\hline \multirow[t]{2}{*}{ M0 } & 0.00 & $-0.17^{*}$ & -0.03 & -0.12 & -0.01 & 0.01 & 0.00 & -0.04 & 1 & & & & \\
\hline & (0.99) & $(0.06)$ & $(0.76)$ & (0.16) & $(0.90)$ & (0.93) & (0.96) & (0.67) & ---- & & & & \\
\hline \multirow[t]{2}{*}{ M3 } & & 0.03 & -0.11 & 0.09 & -0.01 & 0.02 & 0.00 & 0.02 & 0.12 & 1 & & & \\
\hline & $\begin{array}{l}0.88^{*} \\
(0.00)\end{array}$ & $(0.73)$ & $(0.19)$ & $(0.29)$ & $(0.90)$ & $(0.81)$ & (0.99) & $(0.85)$ & (0.16) & ----- & & & \\
\hline \multirow[t]{2}{*}{ RECEXP } & $-0.46^{*}$ & -0.07 & $0.41^{*}$ & -0.09 & -0.05 & $0.24^{*}$ & $0.76^{*}$ & 0.74 & -0.01 & 0.03 & 1 & & \\
\hline & $(0.02)$ & $(0.42)$ & $(0.00)$ & $(0.32)$ & $(0.58)$ & $(0.01)$ & $(0.00)$ & $(0.00)$ & (0.95) & (0.73) & ----- & & \\
\hline REEXP & $-0.32 *$ & 0.02 & -0.01 & 0.04 & 0.05 & -0.01 & -0.12 & $018 *$ & 0.00 & -0.08 & -0.13 & 1 & \\
\hline & $(0.01)$ & $(0.81)$ & $(0.89)$ & $(0.66)$ & $(0.55)$ & $(0.95)$ & (0.17) & $(0.04)$ & (0.98) & $(0.39)$ & $(0.14)$ & ----- & \\
\hline \multirow[t]{2}{*}{ VAT } & $0.47^{*}$ & -0.01 & $0.36^{*}$ & -0.10 & -0.06 & $0.31^{*}$ & $0.59 *$ & $0.76^{*}$ & -0.03 & 0.02 & $0.67^{*}$ & -0.13 & 1 \\
\hline & $(0.01)$ & $(0.90)$ & $(0.00)$ & $(0.23)$ & $(0.47)$ & $(0.00)$ & $(0.00)$ & $(0.00)$ & $(0.77)$ & $(0.85)$ & $(0.00)$ & $(0.14)$ & ----- \\
\hline
\end{tabular}

Source: Author, (2017). Note that values in parentheses ( ) indicate p-values and * significance at $5 \%$ level of significance.

\subsection{Stationarity}

Table 3 results indicated that inflation, domestic exports (DEXP) and re-exports were integrated of order one based on ADF, PP and KPSS unit root tests. This implied that domestic exports and re-exports became stationary after first difference consistent with the findings of Venkadasalam (2015), Jaradat et al. (2011) and Olatunji et al. (2010).

Table 3: Unit Root Test Results

\begin{tabular}{|c|c|c|c|c|c|c|c|c|c|}
\hline Variable & & & $\begin{array}{l}\text { ADF - } \\
\text { Coeff }\end{array}$ & PP- Coeff & $\begin{array}{l}\text { KPSS- } \\
\text { Coeff }\end{array}$ & $\begin{array}{l}\text { ADF } \\
\text { P- } \\
\text { value }\end{array}$ & $\begin{array}{l}\text { PP P- } \\
\text { value }\end{array}$ & $\begin{array}{l}\text { KPSS- } \\
\text { P- } \\
\text { value }\end{array}$ & Inference \\
\hline \multirow{7}{*}{ INFM } & Level & Intercept & -0.064353 & -0.049284 & 0.084708 & 0.0633 & 0.0735 & 0.0000 & - \\
\hline & & None & -0.017508 & -0.016741 & - & 0.1329 & 0.1859 & - & - \\
\hline & & $\mathrm{I} \& \mathrm{~T}$ & - & -0.047982 & 0.095074 & 0.0068 & 0.0632 & 0.0000 & - \\
\hline & & & $0.064277^{*}$ & & & & & & \\
\hline & \multirow[t]{3}{*}{$\begin{array}{c}1^{\text {st }} \\
\text { diff }\end{array}$} & Intercept & $\begin{array}{c}- \\
0.580570 *\end{array}$ & $\begin{array}{c}- \\
0.580570 *\end{array}$ & $\begin{array}{c}- \\
0.000524 *\end{array}$ & 0.0000 & 0.0000 & 0.6723 & $\mathrm{I}(1)$ \\
\hline & & None & $\begin{array}{c}- \\
0.579952 *\end{array}$ & $\stackrel{-}{0.579952 *}$ & - & 0.0000 & 0.0000 & - & $\mathrm{I}(1)$ \\
\hline & & I \& T & - & $\stackrel{-}{0.581951^{*}}$ & $\begin{array}{c}- \\
0.001905^{*}\end{array}$ & - & 0.0000 & 0.4459 & $\mathrm{I}(1)$ \\
\hline \multirow[t]{3}{*}{ DEXP } & \multirow[t]{3}{*}{ Level } & Intercept & -0.042877 & -0.059909 & 30950.86 & 0.1162 & 0.4791 & 0.0000 & - \\
\hline & & None & 0.005279 & 0.001504 & - & 0.4938 & 0.8558 & - & - \\
\hline & & I \& T & -0.230951 & $\begin{array}{c}- \\
0.323051 *\end{array}$ & 16463.23 & 0.0648 & 0.0000 & 0.0000 & - \\
\hline
\end{tabular}




\begin{tabular}{|c|c|c|c|c|c|c|c|c|c|}
\hline & $\begin{array}{l}1^{\text {st }} \\
\text { diff }\end{array}$ & Intercept & $\stackrel{-}{-}$ & $\stackrel{-}{-}$ & 214.9084* & 0.0000 & 0.0000 & 0.4193 & $\mathrm{I}(1)$ \\
\hline & & None & - & - & - & 0.0000 & 0.0000 & - & $\mathrm{I}(1)$ \\
\hline & & $\mathrm{I} \& \mathrm{~T}$ & $\begin{array}{c}- \\
- \\
1.947121^{*}\end{array}$ & $\begin{array}{c}1.551000 \\
-\end{array}$ & $322.0755 *$ & 0.0000 & - & 0.5486 & $\mathrm{I}(1)$ \\
\hline \multirow[t]{6}{*}{ REEXP } & Level & Intercept & -0.091086 & -0.157404 & 3216.606 & 0.0739 & 0.0927 & 0.0000 & - \\
\hline & & None & -0.018935 & -0.043077 & - & 0.4870 & 0.1317 & - & - \\
\hline & & I \& T & -0.206433 & $\begin{array}{c}- \\
0.270811^{*}\end{array}$ & 1073.990 & 0.0598 & 0.0000 & 0.0006 & - \\
\hline & $\begin{array}{l}1^{\text {st }} \\
\text { diff }\end{array}$ & Intercept & $\begin{array}{c}- \\
1.755380 *\end{array}$ & $\begin{array}{c}- \\
1.397980 *\end{array}$ & $22.17557^{*}$ & 0.0000 & 0.0000 & 0.8394 & $\mathrm{I}(1)$ \\
\hline & & None & $\begin{array}{c}- \\
1.754442 *\end{array}$ & $\begin{array}{c}- \\
1.397540 *\end{array}$ & - & 0.0000 & 0.0000 & - & $\mathrm{I}(1)$ \\
\hline & & $\mathrm{I} \& \mathrm{~T}$ & $\begin{array}{c}- \\
1.783890 *\end{array}$ & - & $\begin{array}{c}- \\
140.8701 *\end{array}$ & 0.0000 & - & 0.5228 & $\mathrm{I}(1)$ \\
\hline
\end{tabular}

Source: Author (2017), Note. * Implies stationary at 5\% level of significance (p-value $<0.05$ for ADF \& PP and p-value $>0.05$ for KPSS), I (0) indicate stationary at level and I (1) indicate integrated of order 1.

\subsection{Johansen Cointegration}

Tables 4 and 5 indicated that there was a long run relationship between the variables of domestic exports and re-exports with inflation in Kenya based on the trace and Eigen value cointegration tests that showed existence of one cointegrating vector. Further, the normalized cointegration results in Table 6 after reversing signs indicated that although inflation exhibited a significant negative long run relationship with re-exports, there was a significant positive long run relationship with domestic exports in Kenya at $5 \%$ level of significance. This implied that a percentage increase in level of re-exports decreases inflation in Kenya by $0.137 \%$ while a percentage increase in domestic exports in Kenya by $1.044 \%$ in the long run.

Comparatively domestic exports highly influenced inflation in Kenya in the long run as opposed to re-exports. The negative long run relationship between re-exports and inflation though inconsistent with a priori expectation conformed to the findings of Ahmed et al. (2013) and Olatunji et al. (2010) who investigated the determinants of inflation in Pakistan and Nigeria respectively while the findings of a positive long run relationship between domestic exports and inflation in Kenya conformed to the findings of Venkadasalam (2015) and Jaradat et al. (2011) who investigated the determinants of inflation in Malaysia and Jordan respectively. This was also consistent to the a priori expectation of a positive relationship.

The negative relationship between re-exports and inflation as explained by Ahmad and Wajid (2013) may be attributed to the fact that higher re-exports increases trade revenue which causes more investment and increased domestic production with firms enjoying economies of scale and reduction in production cost. This increases aggregate supply causing a 
reduction in prices. On the other hand, the positive relationship between inflation, domestic exports and total exports as argued by Joiya and Shahzad (2013) may be due to a shortage of food products in the country since the main exports for Kenya are agricultural products. High demand and reduced supply causes price to rise.

Table 4: Unrestricted Cointegration Rank Test (Trace)

\begin{tabular}{ccccc}
\hline $\begin{array}{c}\text { Hypothesized } \\
\text { No. of CE(s) }\end{array}$ & Eigen value & Statistic & $\begin{array}{c}0.05 \\
\text { Critical Value }\end{array}$ & Prob.** \\
\hline None & 0.867312 & 1257.093 & NA & NA \\
At most $1 *$ & 0.795037 & 1006.643 & 334.9837 & 0.0000 \\
At most 2 & 0.741401 & 810.1123 & 885.1425 & 0.0612 \\
At most 3 & 0.725845 & 642.4053 & 739.2354 & 0.3405 \\
At most 4 & 0.648519 & 481.9419 & 897.3709 & 0.7122 \\
\hline
\end{tabular}

Source: Author (2017). Trace test indicates 1cointegrating eqn (s) at 0.05 level, * denotes rejection of null hypothesis at the 0.05 level and ** MacKinnon-Haug-Michelis (1999) pvalues

Table 5: Unrestricted Cointegration Rank Test (Maximum Eigenvalue)

\begin{tabular}{ccccc}
\hline $\begin{array}{c}\text { Hypothesized } \\
\text { No. of CE(s) }\end{array}$ & Eigenvalue & $\begin{array}{c}\text { Max-Eigen } \\
\text { Statistic }\end{array}$ & $\begin{array}{c}0.05 \\
\text { Critical Value }\end{array}$ & $\begin{array}{c}\text { Prob.** } \\
\text { None }\end{array}$ \\
0.867312 & 250.4494 & NA & NA \\
At most $1 *$ & 0.795037 & 196.5310 & 76.57843 & 0.0000 \\
At most 2 & 0.741401 & 167.7070 & 170.53513 & 0.0832 \\
At most 3 & 0.725845 & 160.4634 & 264.50472 & 0.7142 \\
At most 4 & 0.648519 & 129.6543 & 158.43354 & 0.0623 \\
\hline
\end{tabular}

Source: Author (2017). Max-eigenvalue test indicates 1cointegrating eqn (s) at 0.05 level, * denotes rejection of null hypothesis at the 0.05 level and ** MacKinnon-Haug-Michelis

(1999) p-values

Table 6: Normalized Cointegration Coefficients for Disaggregate Analysis

\begin{tabular}{ccccccccccccc}
\hline INFM & CIMP & DEVEXP & DEXP & ED & GIMP & ID & IT & M0 & M3 & RECEXP & REEXP & VAT \\
1.000 & $0.528^{*}$ & $0.002^{*}$ & - & - & - & - & 0.573 & 0.746 & - & $0.179^{*}$ & $0.137 *$ & - \\
& & & $1.044^{*}$ & $0.041^{*}$ & $0.004^{*}$ & $0.506^{*}$ & & & $1.751^{*}$ & & & $0.490^{*}$ \\
& {[} & {$[2.747]$} & {$[-$} & {$[-$} & {$[-$} & {$[-$} & {[} & {[} & {$[-$} & {$[2.863]$} & {$[4.307]$} & {$[-$} \\
& $3.904]$ & & $5.294]$ & $4.720]$ & $3.966]$ & $3.474]$ & $3.473]$ & $1.620]$ & $2.291]$ & & & $2.611]$
\end{tabular}

Source: Author (2017). T-statistics in parentheses [ ], Sample 131, included 124 observation after adjustment with t-critical value 1.98 at 5\% significance level. * indicate significant at $5 \%$ level of significance.

\subsection{Impulse Response}

Figure 1 indicated that the response of inflation to one standard deviation innovation to domestic exports had a positive effect on inflation in Kenya that fizzled out after the $40^{\text {th }}$ month. Re-exports had an explosive negative effect on inflation in Kenya up to the $30^{\text {th }}$ month after which the effect dampened with a stable path that did not fizzle out as in Figure 2. The results corroborated the cointegration findings at $5 \%$ level of significance and were consistent with the findings of Olatunji et al. (2010) and 
Venkadasalam (2015) who investigated the determinants of inflation in Nigeria and Malaysia respectively.

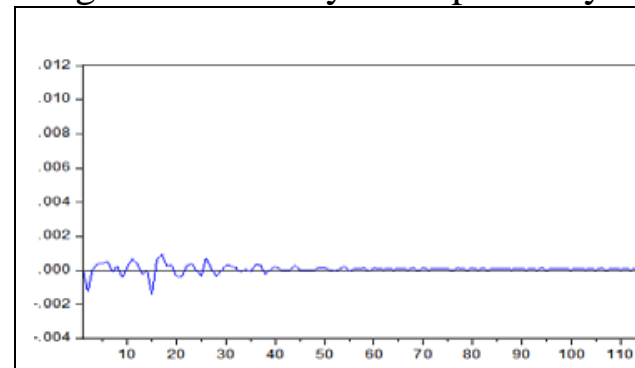

Figure 1. Response of inflation to domestic exports (Author, 2017).

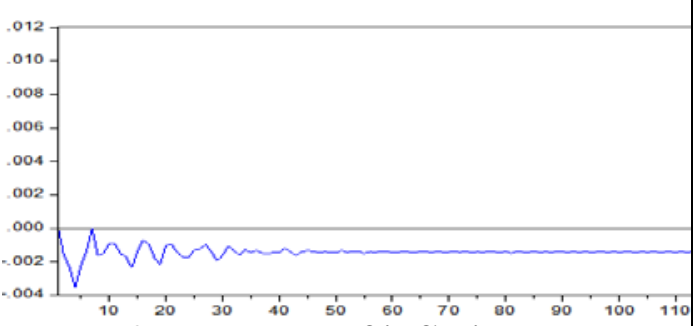

Figure 2. Response of inflation to reexports (Author, 2017).

\subsection{Causality}

Tables 7 indicated that there was unidirectional causality from domestic exports to inflation and re-exports to inflation in Kenya at $5 \%$ level of significance. The results implied that the null hypothesis of no causality between exports and inflation in Kenya was rejected at 5\% level of significance an indication that both domestic exports and re- exports determined inflation in Kenya. The finding conformed to the results of Venkadasalam (2015) who investigated the determinants of inflation in Malaysia.

Table 7: Granger Causality Results

Pair wise Granger Causality Tests

Null Hypothesis:

Obs

F-Statistic

Prob.

DEXP does not Granger Cause INFM

INFM does not Granger Cause DEXP

REEXP does not Granger Cause INFM

INFM does not Granger Cause REEXP

125

4.53705*

0.0191

0.71959

0.6346

Note. * indicate significance at 5\% level of significance (Author, 2017)

\subsection{Conclusion and Recommendations}

The purpose of this study was to examine exports as a determinant of inflation in Kenya: A disaggregated econometric analysis. The specific objectives were to establish the relationship between domestic exports and inflation in Kenya and to determine the relationship between re - exports and inflation in Kenya. The findings of this study clearly indicated that all the time series variables of inflation, domestic exports and re-exports were integrated of order one, i.e. become stationary at the first difference implying 
that they were suitable for analysis. Correlation analysis indicated a weak significant association between re-exports and inflation, a strong significant positive association between domestic exports and inflation in Kenya. There was a significant negative long run relationship between re-exports and inflation in Kenya and a significant positive long run relationship between domestic exports and inflation in Kenya. This was supported by impulse response analysis whereby an increase in re-exports decreased inflation while an increase in domestic exports led to an increase in inflation in Kenya. There was also unidirectional causality from domestic exports to inflation and re-exports to inflation in Kenya. It was noted that domestic exports highly influenced inflation in Kenya. In conclusion domestic exports and re-exports were established as determinants of inflation in Kenya.

It is against these empirical findings that the study recommended that the government of Kenya must advocate for a trade policy that strikes a balance between the local demand and the output for domestically produced products. This will ensure that only surplus is exported to reduce shortage of domestically produced commodities that may be brought about by curtailing unwarranted exports of domestically produced products especially food products at the expense of local consumers. This will reduce domestic exports and hence a reduction in price for the products. The government should also consider providing incentives like tax rebate for re-exporters to encourage value addition to increase re-exports. This will generate more trade revenues that will be invested in the economy increasing aggregate supply of products as a result of increased domestic production that will reduce prices. A reduction in domestic exports and an increase in re-exports will lead to a balance and a reduction in total exports that will reduce inflation in Kenya.

These study although conducted disaggregated analysis, the variables of re-exports and domestic exports can be disaggregated further. This made the relationship between; inflation and domestic exports components, inflation and re-exports components inconclusive. The study therefore recommends that future studies to further disaggregate domestic exports and re-exports which will generate knowledge on how the respective factors of the exports components relate with inflation in Kenya.

\section{References:}

1. Ahmed, F., Raza, H., Hussain, A., \& Lal, I. (2013). Determinant of inflation in Pakistan: An econometrics analysis, using Johansen cointegration approach. European Journal of Business and Management , 5 (30), 115-122. 
2. Arif, M., \& Ali, M. M. (2012). Determinants of inflation in Bangladesh: An empirical investigation. Journal of Economics and Sustainable Development , 3 (12), 9-17.

3. Bashir, F., Nawaz, S., Yasin, K., Khursheed, U., Khan, J., \& Qureshi, M. J. (2011). Determinants of inflation in Pakistan: An econometric analysis using Johansen co-integration approach. Australian Journal of Business and Management Research , 1 (5), 71-82.

4. Central Bank of Kenya. (2015). Monetary policy statement: December 2015. Nairobi: Central Bank of Kenya.

5. Government of Kenya. (2016). Economic survey 2016. Nairobi: Kenya National Bureau of Statistics.

6. Government of Kenya. (2010). Kenya economic survey 2010 highlights. Nairobi: Kenya National Bureau of Statistics.

7. Gylfason, T. (1997). Exports, inflation and growth . Washington, D.C.: International Monetary Fund Working paper 119.

8. Jaradat, M., Al-Zeaud, H. A., \& Al-Rawahneh, H. (2011). An econometric analysis of the determinants of inflation in Jordan. Journal of Middle Eastern Finance and Economics , 15, 121-132.

9. Joiya, S. A., \& Shahzad, A. A. (2013). Determinants of high food prices: The case of Pakistan. Pakistan Economic and Social Review, 51 (1), 93-107.

10. Khan, U. R. (2013). Relationship between fluctuated exports and economic growth of Pakistan. International Journal of Business and Management , 21, 108-113.

11. Njuru, S. G. (2012). Effects of fiscal policy on private investment in Kenya (1964- 2010) (unpublished doctoral thesis). Kenyatta University. Nairobi: Kenyatta University.

12. Olatunji, G. B., Omotesho, O. A., Ayinde, O. E., \& Ayinde, K. (2010). Determinants of inflation in Nigeria: A co-integration approach. Joint 3rd African Association of Agricultural Economists (AAAE) and 48th Agricultural Economists Association of South Africa (AEASA) Conference (pp. 19-23). Cape Town: Institution of Economic Research and Innovation (IERI).

13. Ramzan, D., Fatima, K., \& Yousaf, Z. (2013). An analysis of the relationship between Inflation and trade openness. Interdisciplinary Journal of Contemporary Research jn Business , 5 (3), 215-229.

14. Rehman, F. U., \& Khan, D. (2015). The determinants of food price inflation in Pakistan: An econometric analysis. Advances in Economics and Business , 3 (12), 571-576.

15. Shah, M. A., Aleem, M., \& Arshed, N. (2014). Statistical analysis of the factors affecting inflation in Pakistan. Middle-East Journal of Scientific Research , 21 (1), 181-189. 
16. Venkadasalam, S. (2015). The determinant of consumer price index in Malaysia. Journal of Economics, Business and Management , 3 (12), 1115 - 1119.

17. World Bank. (2014). World bank development indicators. Washington DC: World Bank. 